\title{
Five New Species of Diplazium Sw. (Athyriaceae) from Nicaragua, Costa Rica and Colombia
}

\author{
Alexander Francisco Rojas-Alvarado \\ Universidad Nacional, Heredia, Costa Rica \\ Email: alfrojasa@yahoo.com
}

How to cite this paper: Rojas-Alvarado, A.F. (2018) Five New Species of Diplazium Sw. (Athyriaceae) from Nicaragua, Costa Rica and Colombia. American Journal of Plant Sciences, 9, 933-945.

https://doi.org/10.4236/ajps.2018.95071

Received: December 17, 2017

Accepted: April 10, 2018

Published: April 13, 2018

Copyright $\odot 2018$ by author and Scientific Research Publishing Inc. This work is licensed under the Creative Commons Attribution International License (CC BY 4.0).

http://creativecommons.org/licenses/by/4.0/

(c) (i) Open Access

\begin{abstract}
Five new species are described in the genus Diplazium Sw. from Nicaragua, Costa Rica and Colombia, as results of studies in the Neotropical ferns. The new species are Diplazium chirripoense A. Rojas, Diplazium cornutum A. Rojas, Diplazium crassirhizoma A. Rojas, Diplazium lustrosum A. Rojas and Diplazium rodriguezii A. Rojas. The first species is related to D. skutchii Lellinger, but differs from it by having glabrous stipe, glabrous blade abaxially, hyaline and entire indusia, and distributed and higher elevations. The second species is different to $D$. diplazioides (Klotzsch et $\mathrm{H}$. Karst.) Alston by having densely scaly stipe, rachis and costa, relative bigger pinnae and entire to erose indusia. After that, the third species differs from $D$. werckleanum Christ by thicker rhizome, bigger rhizome scales and blade with $1-2$ [1] buds at apex. Consecutively, the fourth species differs from $D$. lindbergii (Mett.) H. Christ by thinner rhizome, shorter fronds, longer stipe, smaller blade, less pinnae pairs, shiny laminar tissue and veins 3 - 5 pairs per segment. Finally, the fifth species is related to $D$. tungurahuae (Sodiro) C. Chr., but with abaxially glabrous rachis and costae, pinnules 4 - 5 times longer than wide and entire, costules adaxially without wings, veins abaxially glabrous and reticulate along costae and between pinnate veins.
\end{abstract}

\section{Keywords}

Athyriaceae, Diplazium, Ferns, Neotropics, Taxonomy

\section{Introduction}

Mickel and Smith [2] indicate that Diplazium Sw. comprises about 350 - 400 species, with probably more than 150 in the New World; this is a genus of humid tropical forests at low to medium (rarely high) heights.

Mickel and Smith [2] define the genus Diplazium for presenting commonly 
indusiate sori that are elongated and at least sometimes paired with dorsum along the veins, relatively thick roots, erected to suberect rhizomes, two vascular bundles as ribbons and a chromosomal base number of $\mathrm{x}=41$. Additionally, Moran [3] indicates that the vascular bundles are connected distally to form a U-shaped vascular bundle, and that the sporangium ring consists of 15 - 20 cells.

Mickel and Smith [2] indicate that a monographic study in Diplazium is necessary for a better understanding of the species and their relationships. Moran [3] mentions that in the Neotropics, few genera of ferns have received so little study as Diplazium, consequently, there are numerous taxonomic and nomenclatural problems.

Tryon and Stolze [1] indicate that the key they use artificially separates many species according to the degree of laminar dissection, and although this character frequently helps in the separation of certain taxa, there is evidence to suggest that this is a poor indicator of relationship between species. Schuettpelz and Pryer [4] performed molecular studies and cladistic analysis with 400 species of leptosporangiate ferns and found that Diplazium is separated into two large clades, one of which is characterized by the development of acroscopic lobules in the pinna, pinnulae or segments, and another that does not has this feature. Four species treated here belong to the second group, and only D. crassirhizoma is on the first group.

As part of the author's taxonomic studies on neotropical ferns, five new species are described here from Nicaragua, Costa Rica and Colombia.

\section{Materials and Methods}

The new species here considered are the result of comparisons with specimens of other Neotropical species, and a review of related species and keys from the neotropical ferns by: Adams [5], Gómez \& Arbeláez [6], Mickel \& Smith [2], Murillo, Murillo \& León [7], Smith [8], Stolze [9], Stolze, Pacheco \& Øllgaard [10], Tryon \& Stolze [1], and other papers where new species were described in the Diplazium genus, for example: Adams, C.D. [11], Kessler \& Smith [12], Lorea \& Smith [13], Mickel \& Smith [14], Pacheco [15], Pacheco \& Moran [16], Pacheco \& Smith [17], Rojas A.F. [18] [19] [20] [21]. The examined specimens are deposited in the following herbaria CR, COL, K, MO, MEDEL and USJ (acronyms following Thiers [22]). To ensure the correct application names, original type material or digital type images were examined as available (Jstor Global Plants (http://plants.jstor.org/)), and the new names were corroborated with International Plant Name Index (http://www.ipni.org/ipni/plantnamesearchpage.do).

\section{Results}

\subsection{New Species}

\subsubsection{Diplazium chirripoense A. Rojas, sp. nov. (Figure 1)}

TYPE: COSTA RICA. San José: Pérez Zeledón, San Gerardo de Rivas, Chirripó National Park, trail to Cerro Chirripó, before km 8 turn left, in trail to creck, 


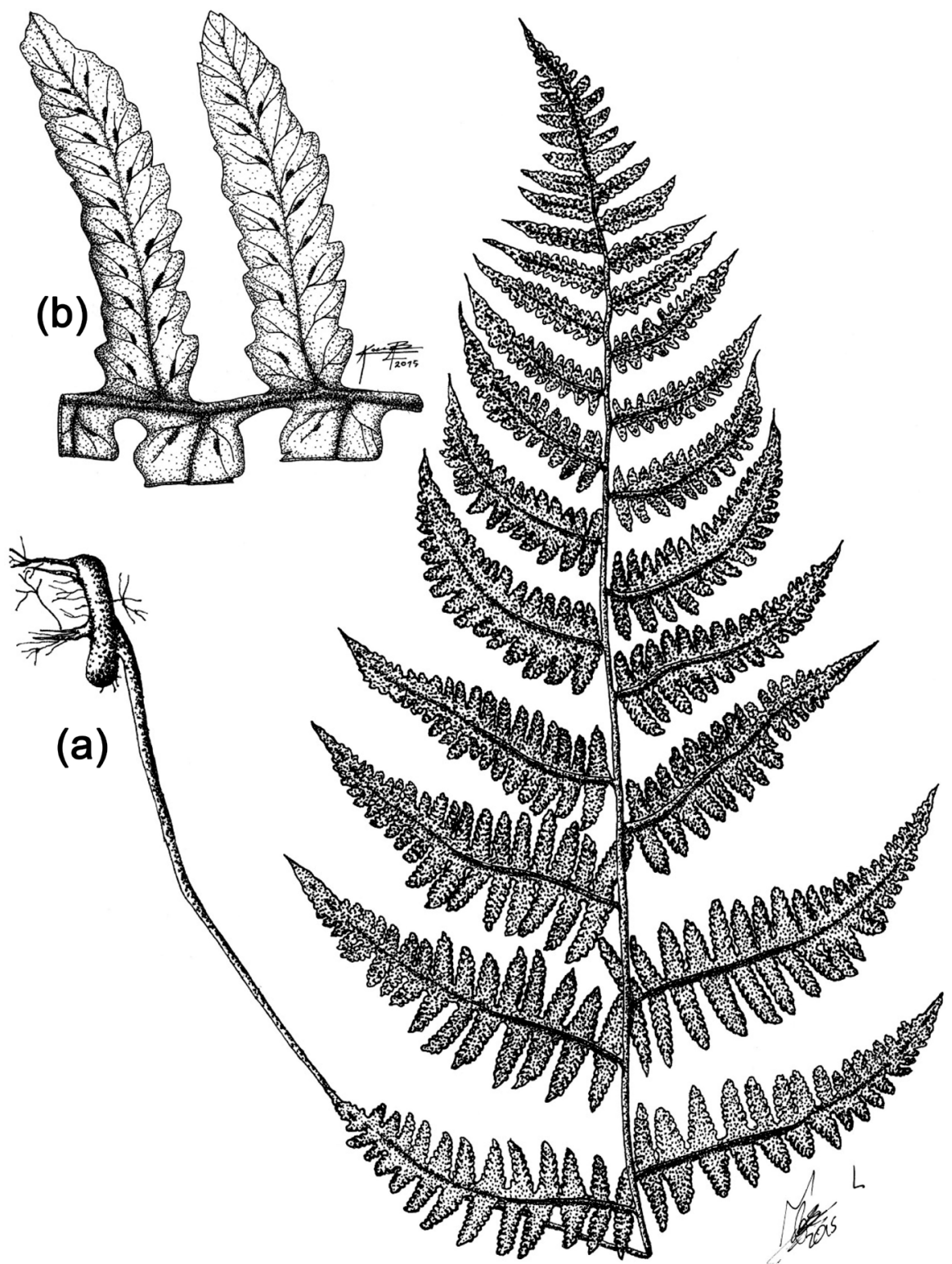

Figure 1. Type specimen of Diplazium chirripoense A. Rojas (A. Rojas 11,276, CR). (a) General aspect of type specimen; (b) Abaxial blade detail.

$9^{\circ} 27^{\prime} 13^{\prime \prime N}, 83^{\circ} 32^{\prime} 28^{\prime \prime} \mathrm{W}, 2500$ - 2600 m, 10 abr 2016, A. Rojas 11,276 (holotype: CR; Isotypes: MO, USJ).

Diagnoses. Diplazium chirripoense A. Rojas differs from D. skutchii Lellinger for stipe glabrous; blade glabrous abaxially; indusia hyaline and entire, and distribute and higher elevations.

Description. Rhizome $1-2 \mathrm{~cm}$ in diameter, ascending $5-20 \mathrm{~cm}$; rhizome scales 8 - $12 \times 1-2 \mathrm{~mm}$, narrowly lanceolate to linear-lanceolate, grayish-brown, opaque, ending in a piliform and crispate apex, non-fenestrated or reticulate, marginally entire; fronds $120-145 \mathrm{~cm}$ long, fasciculate; stipe $53-66 \mathrm{~cm}$ long, markedly ascending basally, yellowish-brown to dark brown, sparsely scaly, the scales $4-10 \times 1-3 \mathrm{~mm}$, lanceolate, yellowish-brown, very sparse, also with 
dense squamules and trichomes, them less than $1 \mathrm{~mm}$ long, brown; blade 57 - 80 $\times 50-70 \mathrm{~cm}$, deltate-lanceolate, 2-pinnate lobulate to 2-pinnate-pinnatifid; rachis, costa and costules yellowish-brown to dark brown, glabrescent to sparsely scaly, the scales $2-5 \times 0.5-1 \mathrm{~mm}$, linear, yellowish-brown; basal and medial pinnae $18-35 \times 8-13 \mathrm{~cm}, 8-12$ free pairs, longest at blade base, lanceolate, equilateral, pediculate to $1 \mathrm{~cm}$ long, acute and pinnatifid at apex; pinnules 4.5 $6.5 \times 0.8-1.6 \mathrm{~cm}, 10-15$ pairs, to 5 free pairs, lanceolate-oblong to oblong, truncate at base, incised to $1 / 2$ between central vein and margin, acute at apex; lobes 5 - 11 per pinnule, oblique, entire, obtuse to rounded at apex, glabrous, herbaceous, green, scarcely discolorous; veins single to 2-bifurcate, glabrous; sori 1.5 - $2.5 \mathrm{~mm}$, the proximal ones doubles; indusia $0.2-0.4 \mathrm{~mm}$ broad, hyaline, entire, deciduous or fragmented into maturity.

Etimology. The specific epithets of this species make reference to the type locality.

Distribution. Actually known only from Chirripó National Park in San José, Costa Rica, at 2500 - $2830 \mathrm{~m}$.

Additional revised material. COSTA RICA. San José: Pérez Zeledón, San Gerardo de Rivas, Parque Nacional Chirripó, trail to Cerro Chirripó, before km 8 , trail to creek and continue to Basín river, $9^{\circ} 27^{\prime} 13^{\prime \prime} \mathrm{N}, 83^{\circ} 32^{\prime} 28^{\prime \prime} \mathrm{W}, 2500-2600$ m, 18 jun 2016, A. Rojas \& P. Muñoz 11,420 (CR, K, MO).

Notes. Diplazium chirripoense A. Rojas differs from $D$. skutchii for stipe glabrous (vs. puberulent); blade glabrous abaxially (vs. hairy); indusia hyaline (vs. brown), entire (vs. fimbriate to long ciliate) and evanescent (vs. persistent), and distribute and higher elevations (2500 - $2850 \mathrm{~m}$ vs. $520-1770 \mathrm{~m})$. Also is similar to $D$. expansum Willd. in glabrous and pale green blade, but differ in its lighter (grayish-brown vs. dark brown) rhizome scales; glabrous (vs. puberulent) stipe, rachis and costae; less divided (1-pinnate-pinnatifid vs. 2-pinnate-pinnatifid) blade, entire (vs. fimbriate to ciliate) indusia and distribute and higher elevations (2500 - $2850 \mathrm{~m}$ vs. $1000-1300 \mathrm{~m})$.

\subsubsection{Diplazium cornutum A. Rojas, sp. nov. (Figure 2)}

TYPE: COSTA RICA. San José: Pérez Zeledón, San Gerardo de Rivas, Chirripó National Park, trail to Cerro Chirripó, between Llano Bonito Station and km 9, $9^{\circ} 27^{\prime} 15^{\prime \prime} \mathrm{N}, 83^{\circ} 32^{\prime} 40^{\prime \prime} \mathrm{W}, 2500$ - $2830 \mathrm{~m}$, A. Rojas \& J. Tenorio 11,108 (holotype: CR; Isotypes: $\mathrm{K}, \mathrm{MO}, \mathrm{USJ})$.

Diagnoses. Diplazium cornutum A. Rojas differs from $D$. diplazioides (Klotzsch et H. Karst.) Alston for densely scaly stipe rachis, and costa; relative bigger pinnae and entire to erose indusia.

Description. Rhizome $1.5-3 \mathrm{~cm}$ in diameter, $5-20 \mathrm{~cm}$ high; compact to short-ascending; Rhizome scales $8-15 \times 2-3 \mathrm{~mm}$, lanceolate, dark brown to blackish, subclathrate, marginally densely and irregularly denticulate; fronds 150 - $230 \mathrm{~cm}$, fasciculate; stipe $65-92 \mathrm{~cm}$ broad, $1-2 \mathrm{~cm}$ in diameter, brown to dark brown, scaly, the scales in two types, ones $10-13 \times 1.5-2 \mathrm{~mm}$, linear-lanceolate, irregularly denticulate as rhizome scales, the others $2-8 \times 0.5-1.5 \mathrm{~mm}$, 


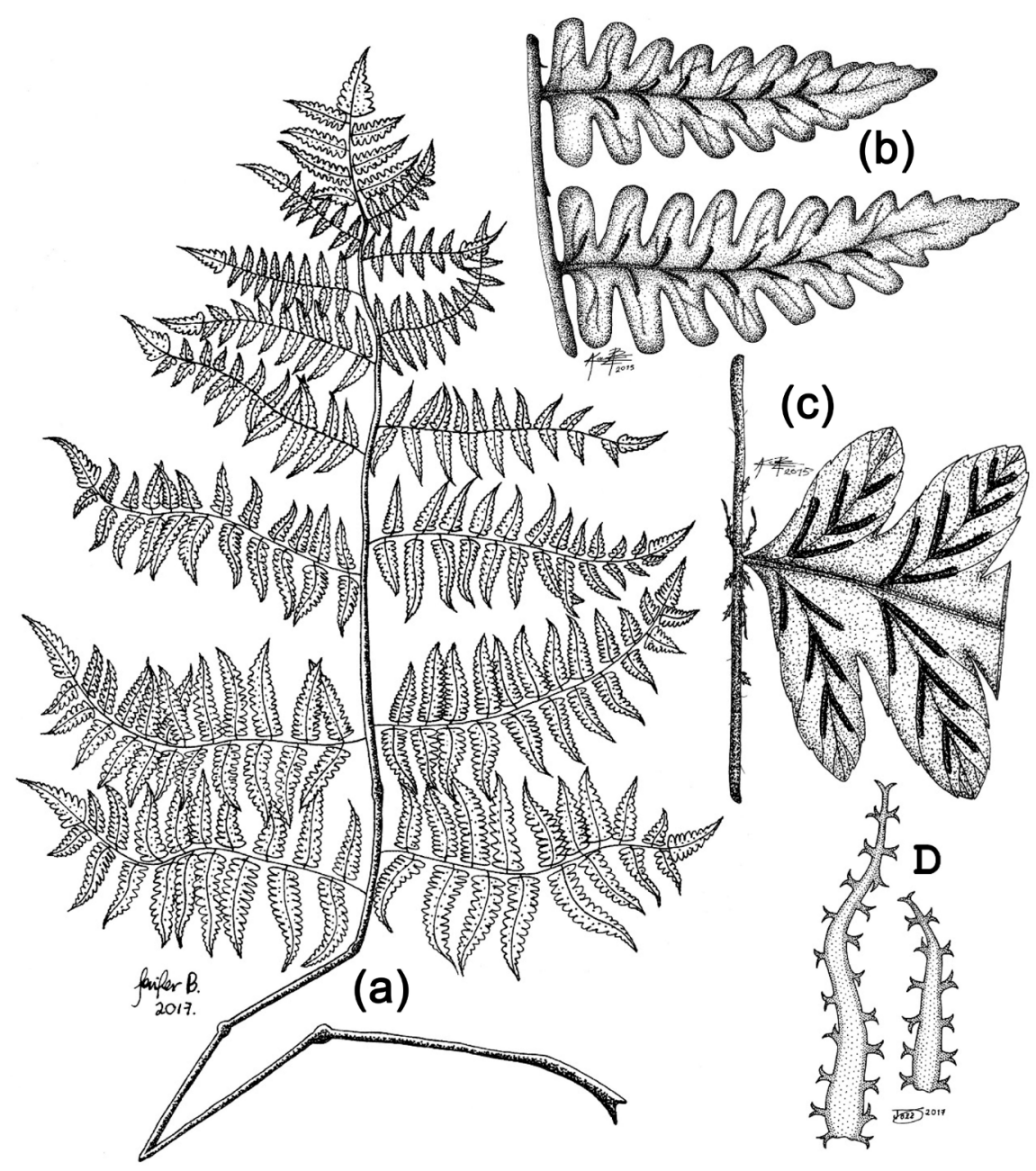

Figure 2. Type specimen of Diplazium cornutum A. Rojas (A. Rojas \& J. Tenorio 11108, CR). (a) General aspect of type specimen; (b) Abaxial blade detail; (c) Costal and pinnule base detail; (d) Costal scales.

linear-lanceolate, more dense, marginally with bifid teeth; blade 90 - $135 \times 80$ - 100 $\mathrm{cm}$, lanceolate, 2-pinnate-lobulate to 2-pinnate-pinnatifid, few reduced at base, acuminate at apex; rachis, costa and costules scaly, the scales $2-8 \times 0.2-0.4$ $\mathrm{mm}$, linear, brown-yellowish in the center and dark brown marginally, dense, marginally with bifid teeth; pinnae 6 - 8 free pairs, (33-) 40 - $52 \times(12-) 17-25$ $\mathrm{cm}$, lanceolate to lanceolate-oblong, equilateral or broader basiscopically, few reduced at base, the basal ones pediculate to $3 \mathrm{~cm}$; pinnules $6-14 \times 2.5-4.5 \mathrm{~cm}$, 9 - 12 free pairs, lanceolate, pediculate to $8 \mathrm{~mm}$, incised $1 / 2-2 / 3$ between costule and margin; ending segments or lobes $5-20 \times 5-10 \mathrm{~mm}$, oblique ovate to oblong, chartaceous, darker in adaxial surface; veins 4 - 7 pairs per segment, single, glabrous; sori 2 - $5 \mathrm{~mm}$ long, ascending, single, rarely diplazioid proximally in the acroscopic side; indusia ca. $1 \mathrm{~mm}$ broad, brown-yellowish to brown, marginally entire to erose, fragmented at the maturity.

Etimology. The specific epithets of this species make reference to rhizome, stipe, rachis and costae covering by scales with bifid teeth (like horns) along the 
margins.

Distribution. Actually known only from Costa Rica at 2100 - $2830 \mathrm{~m}$.

Additional revised material. COSTA RICA. San José: Acosta, Cangrejal, Candelaria Valley, Caraigres Hill, ascending by pastures, $9^{\circ} 43^{\prime} 40^{\prime \prime} \mathrm{N}, 84^{\circ} 08^{\prime} 22^{\prime \prime} \mathrm{W}$, 2100 - 2300 m, 28 Feb 2015, A. Rojas \& W. Baaijen 10,988 (CR, MO); Pérez Zeledón, San Gerardo de Rivas, Chirripó National Park, trail to Cerro Chirripó, before $\mathrm{km} 8$, trail to creek and continue to Basín river, $9^{\circ} 27^{\prime} 13^{\prime \prime} \mathrm{N}, 83^{\circ} 32^{\prime} 28^{\prime \prime} \mathrm{W}$, 2500 - 2600 m, 18 June 2016, A. Rojas \& P. Muñoz 11421 (CR, K, MO).

Notes. Diplazium cornutum differs from $D$. diplazioides for densely scaly (glabrescent) stipe, rachis and costa; relative bigger ((33-) $40-52 \times(12-) 17-25$ cm vs. (15-) 25 - $40 \times(3-) 11-15 \mathrm{~cm}$ ) pinnae and entire to erose (vs. fimbriate to long ciliate) indusia.

\subsubsection{Diplazium crassirhizoma A. Rojas, sp. nov. (Figure 3)}

TYPE: COSTA RICA. Guanacaste: Liberia, Guanacaste National Park, Santa María site, trail to Santa María Vulcan, down place, $10^{\circ} 48^{\prime} 01^{\prime \prime N}, 85^{\circ} 19^{\prime} 02^{\prime \prime W}$, 1300 - 1500 m, 3 Sep 2012, A. Rojas et al. 10,234 (holotype: CR; Isotypes: K, MO, USJ).

Diagnoses. Diplazium crassirhizoma A. Rojas differs from $D$. werckleanum Christ for thicker rhizome, bigger rhizome scales and blade with 1 - 2 [1] buds at apex.

Description. Rhizome to $10 \times 4-6 \mathrm{~cm}$ (including stipe bases), thick, erect; rhizome scales 5 - $10 \times 2-3 \mathrm{~mm}$, lanceolate, blackish, shine, entire; fronds 40 $75 \mathrm{~cm}$ long, fasciculate, arching; stipe $20-35(-43) \times 0.2-0.4 \mathrm{~cm}$, pale brown to green-strawish, scaly at the base, the scales as the rhizome, up glabrous; blade 20 - $40 \times 15-27 \mathrm{~cm}$, deltate to broadly ovate, 1-pinnate, basally truncate, apically pinnatifid and acuminate, with 1 - 2 [1] axillar buds in terminal pinnae; pinnae (6-) 8 - 12 pairs, 8 - $15 \times 1.3$ - $3 \mathrm{~cm}$, linear-lanceolate, subcoriaceous, green when dry, discolor, abaxially lighter, pediculate to $8 \mathrm{~mm}$, sometimes with a short acroscopic lobe, basally cuneate, marginally lobulate to crenate-serrulate throughout, apically acute to long acuminate and falcate, glabrous; veins 2-4(-6)-bifurcate; sori 5 - $12 \mathrm{~mm}$, the longest generally duplicate, curved and present in the acroscopic side, burning to $1 \mathrm{~mm}$ or more than the costa, the shortest distally or near the margin; indusium $0.6-0.8 \mathrm{~mm}$ broad, brown, opaque, marginally entire and here lighter, reflexuous at maturity.

Etimology. The specific epithets make reference to the thick rhizome.

Distribution. Actually known only from Nicaragua and Costa Rica at 1100 $2230 \mathrm{~m}$.

Additional revised material. NICARAGUA. Jinotega: along hwy. 3 from Jinotega to Matagalpa, ca. 5 - 8 mi SW of Jinotega, 1500 m, 7 Aug 1977, T. Croat 43,067 (CR, MO); Miraflores, ca. $26.1 \mathrm{~km}$ (by road) NE of hwy. 1 at Estelí, ca. $13^{\circ} 15^{\prime} \mathrm{N}, 86^{\circ} 15^{\prime} \mathrm{W}, 1250-1300 \mathrm{~m}, 10-11$ June 1981, J. Henrich \& W Stevens 225 (CR, MO); along hwy. 3 between Matagalpa and Jinotega, ca. $4 \mathrm{~km} \mathrm{NW}$ of Aranjuez entrance, ca. $13^{\circ} 02^{\prime} \mathrm{N}, 85^{\circ} 55^{\prime} \mathrm{W}$, ca. $1400 \mathrm{~m}, 28$ Sep 1982, W. Stevens \& 


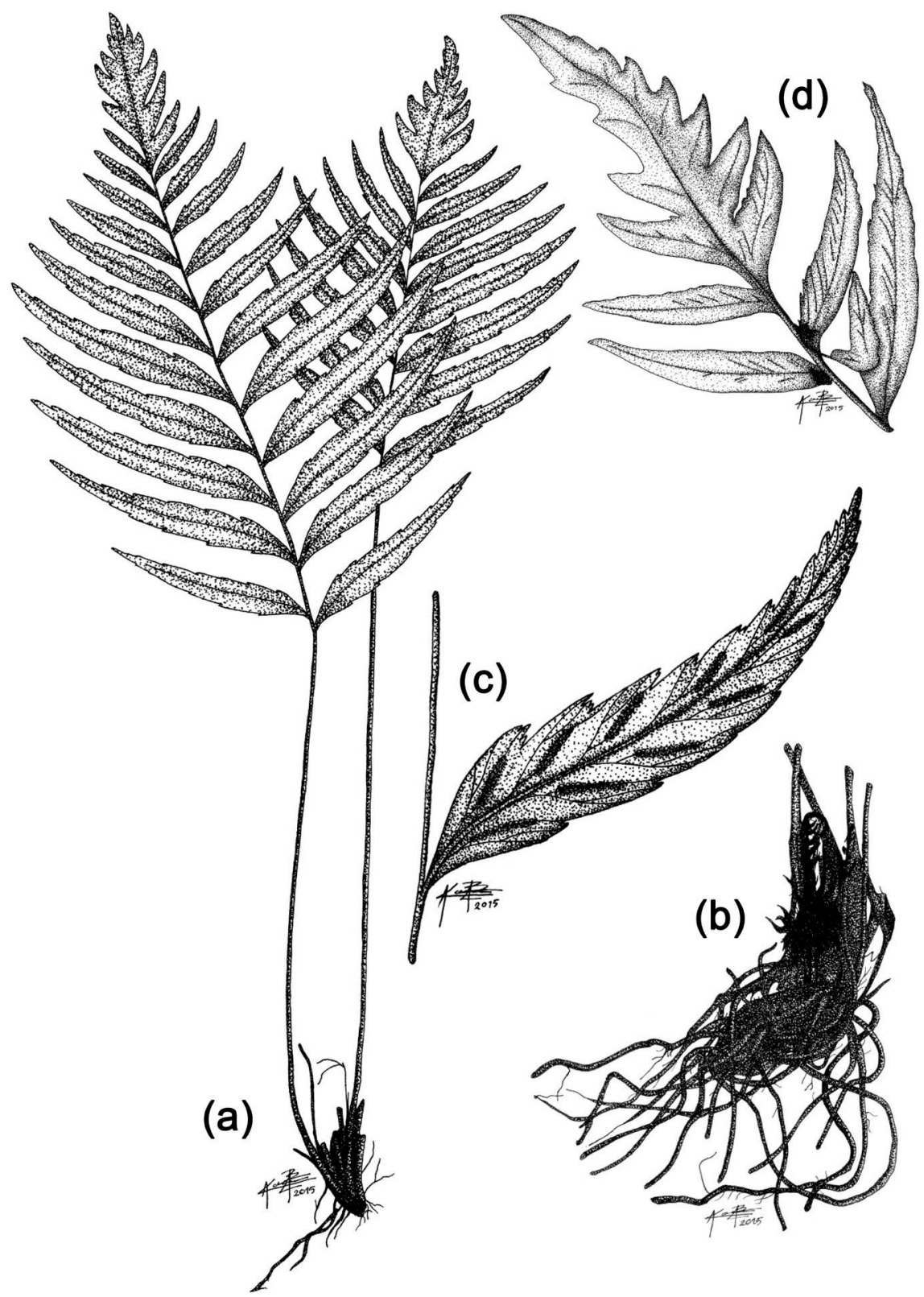

Figure 3. Type specimen of Diplazium crassirhizoma A. Rojas (A. Rojas et al. 10,234, CR). (a) General aspect of specimen; (b) Rhizome detail; (c) Pinna detail; (d) Blade apex detail.

B. Krukoff 21,871 (CR, MO); ca. $1.5 \mathrm{~km}$ from hwy. 3 on road to Aranjuez, ca. $13^{\circ} 02^{\prime} \mathrm{N}, 85^{\circ} 55^{\prime} \mathrm{W}, 1360$ - $1380 \mathrm{~m}, 14 \mathrm{Jan}$ 1978, W. Stevens et al. 5977 (CR, MO); along hwy. 3 between Matagalpa and Jinotega, ca. $1.9 \mathrm{~km}$ NW of Aranjuez road entrance, near $\mathrm{km} 145$, ca. $13^{\circ} 02^{\prime} \mathrm{N}, 85^{\circ} 55^{\prime} \mathrm{W}, 1460-1480 \mathrm{~m}, 7$ may $1980, W$. Stevens et al. 17,008 (CR, MO).

COSTA RICA. Guanacaste: Liberia, Rincón de la Vieja National Park, Santa María site, trail between Pailas and Santa María stations, trail to Santamaría Vulcan, of intersection between them to camping site, $10^{\circ} 48^{\prime} 01^{\prime \prime} \mathrm{N}, 85^{\circ} 19^{\prime} 02^{\prime \prime} \mathrm{W}$, 1300 - 1500 m, 24 Jan 2015, A. Rojas 10,931 (CR, MO). Heredia: Volcán Barba, 
2000 m, L. Gómez 600 (CR); vicinity of Porrosatí, S slope Volcán Barva, 1006'N, 8407'W, 1960 - 2000 m, 3 Apr 1987, M. Grayum et al. 8251 (CR, MO); Barba Vulcan, Porrosatí, 2000 m, 16 Aug 1940, J. León 32 (CR). Puntarenas: Coto Brus, Las Tablas Protected Zone, Térraba-Sierpe Basin, trail to Cerro Echandi, $8^{\circ} 59^{\prime} 11^{\prime \prime N}, 82^{\circ} 49^{\prime} 11^{\prime \prime W}, 2230$ m, 19 Nov 1997, B. Gamboa 1939 (CR, INB, MO); Coto Brus, Las Tablas Protected Zone, Térraba-Sierpe Basin, $8 \mathrm{~km}$ NE of Progreso, 858'30"N, 82²6'15"W, 1960 m, 19 Feb 1997, B. Gamboa \& A. Picado 1054 (CR, INB, MO); E of hairpin ca. $1 \mathrm{~km}$ SE of Las Alturas de Cotón, on road from San Vito, $8^{\circ} 56^{\prime} \mathrm{N}, 82^{\circ} 50^{\prime} \mathrm{W}, 1390$ - 1440 m, 13 July 1985, M. Grayum \& B. Hammel 5670 (CR, MO); Coto Brus, Las Tablas Protected Zone, Térraba-Sierpe Basin, Las Alturas de Cotón, Las Alturas Biological Station, trail to Cerro Echandi, 857'15"N, 8250'10"W, 1580 - 1620 m, 9 Feb 1999, A. Jiménez et al. 1 (CR, INB, MO); Coto Brus, Las Tablas Protected Zone, Térraba-Sierpe Basin, trail to Coto Brus site, $8^{\circ} 57^{\prime} 56^{\prime \prime} \mathrm{N}, 82^{\circ} 46^{\prime} 54^{\prime \prime} \mathrm{W}, 1800 \mathrm{~m}, 11$ Feb 1999, A. Jiménez et al. 30 (CR, INB, MO); Talamanca, ca. $10 \mathrm{~km} \mathrm{~N}$ of La Tigra, 27 Feb 1988, R. Moran 4171 (CR, MO); Coto Brus, Las Tablas Protected Zone, Talamanca Mountains, Sabalito, Las Alturas de Cotón, between Cotón and Las Alturas Biological Station, $8^{\circ} 56^{\prime} 25^{\prime \prime} \mathrm{N}, 82^{\circ} 50^{\prime} 15^{\prime \prime} \mathrm{W}, 1340$ - $1580 \mathrm{~m}, 20$ Dec 1993, A. Rojas 728 (CR, INB, MO); Coto Brus, Zona Protectora Las Tablas, Talamanca Mountains, Sabalito, Las Alturas de Cotón, trail to Cerro Echandi, poles 23 - 40, 858'20"N, 8250'05"W, 1840 - 2200 m, 25 Dec 1993, A. Rojas 811 (CR, INB, MO). San José: Pérez Zeledón, Chirripó National Park, Talamanca Mountains, San Gerardo, trail to Chirripó, begining Cuesta Termómetro, 9²8'15"N, 83³5'10"W, $1100 \mathrm{~m}$, 31 Jul 1996, A. Rojas \& B. Gamboa 2942 (CR).

Notes. Diplazium crassirhizoma differs from $D$. werckleanum for thicker (4 $6 \mathrm{~cm}$ in diameter including stipe bases vs. $1.5-3.0 \mathrm{~cm})$ rhizome, bigger $(5-10 \times$ 2 - $3 \mathrm{~mm}$ vs. $1-4 \times 0.5-1.5 \mathrm{~mm}$ ) rhizome scales and blade with $1-2$ [1] buds at apex (vs. no proliferous apex). Also it's similar to Diplazium errans Lorea-Hern. \& A.R. Sm. because both has proliferous buds at blade apex, but D. crassirrizoma differs in its longer $(5-10 \times 2-3 \mathrm{~mm}$ vs. $0.5-1.0 \times 0.5 \mathrm{~mm})$ rhizome scales; longer (ca. 1/2 of the frond length vs. $1 / 3$ - 2/5) stipe; less pinnae pairs ((6-) 8 12 pairs vs. (20-) 24 (-28) pairs) and few inequilateral (vs. markerly inequilateral) pinnae bases with few excavate basiscopisc side (vs. evidently excavate) and a few prominent acroscopic side (vs. with a prominent lobe).

\subsubsection{Diplazium lustrosum A. Rojas, sp. nov. (Figure 4)}

TYPE: COLOMBIA. Cauca: Munchique National Park, El Tambo, La Romelia trail, 2000 m, 26 Jul 1993, N. Ruiz et al. 292 (holotype: COL, N herb. 366,332; isotypes: COL, $\mathrm{N}^{\circ}$ herb. 366,331, $\mathrm{N}^{\circ}$ herb. 526,488).

Diagnoses. Diplazium lustrosum A. Rojas differs from D. lindbergii (Mett.) Christ by its thinner rhizome; shorter fronds; longer stipe; smaller blade; less pinnae pairs; shiny laminar tissue and veins 3 - 5 pairs per segment.

Description. Rhizome $0.4-0.7 \mathrm{~cm}$ in diameter, ascending to erect; rhizome scales $6-12 \times 1-2 \mathrm{~mm}$, linear-deltate, long attenuate, brown, shiny, subclatrate, 


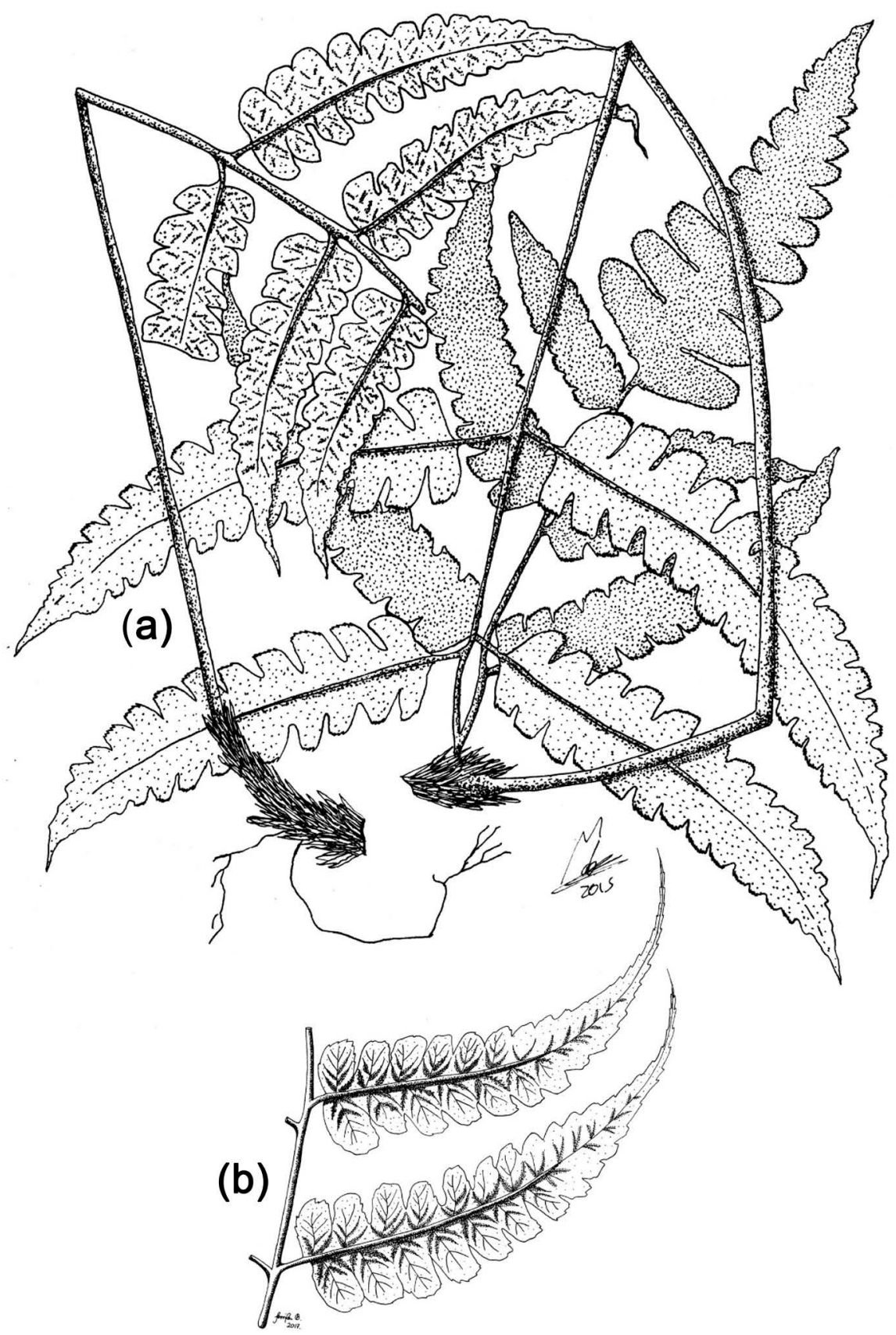

Figure 4. Type specimen of Diplazium lustrosum A. Rojas (N. Ruiz et al. 292, COL). (a) General aspect of specimen' (b) Abaxial blade detail.

entire; fronds 75 - $78.5 \mathrm{~cm}$ long, fasciculate; stipe $39.5-43.5 \times 0.4-0.5 \mathrm{~cm}$, strawish (but blackish at base); blade $35-36 \times 20-27 \mathrm{~cm}$, ovate, 1-pinnate-pinnatifid, chartaceous to subcoriaceous, glabrous and shiny on both surfaces, basally truncate, apically acuminate, discolorous, lighter abaxially; rachis strawish basally, brown to blackish distally, glabrous; pinnae (5.5-) $11-18 \times(1.3-) 2.5-3.6 \mathrm{~cm}, 4$ - 6 pairs, lanceolate to oblong, equilateral, basally obtuse to truncate, apically long acuminate to caudate, incised 3/5 - 3/4 between costa and margin, pediculate, the pedicles to $1.3 \mathrm{~cm}$ long, dark brown to blackish; segments or lobes 10 - 
15 pairs, 6 - $10 \mathrm{~mm}$ broad, ovate to oblong, obliquely curved, marginally dentate, apically obtuse; veins pinnate, 3 - 5 pairs per segment or lobe, single; sori (1-) 3 $6 \mathrm{~mm}$ long, to 4 pairs per segment; indusia $0.2-0.5 \mathrm{~mm}$ broad, pale brown, few evident, glabrous, marginally entire.

Etimology. The name of this species makes reference to lustrous blade.

Distribution. Actually known only for the type collections from Cauca, Colombia at $2000 \mathrm{~m}$.

Notes. Diplazium lustrosum differs from $D$. lindbergii by its thinner (0.4 - 0.7 $\mathrm{cm}$ in diameter vs. $1.5-3.0 \mathrm{~cm}$ ) rhizome; shorter $(75-78.5 \mathrm{~cm}$ long vs. $100-200$ $(-300) \mathrm{cm}$ ) fronds; longer stipe (ca. $1 / 2$ of the frond length vs. ca. $1 / 3)$; smaller $(35-36 \times 20-27 \mathrm{~cm}$ vs. $60-140(-200) \times 30-60(-80) \mathrm{cm})$ blade; less pinnae pairs ( 4 - 6 pairs vs. 12 - 20 pairs); shiny (vs. opaque) laminar tissue and veins 3 5 pairs (vs. 7 - 14 pairs) per segment.

\subsubsection{Diplazium rodriguezii A. Rojas, sp. nov. (Figure 5)}

TYPE: COLOMBIA. Antioquia: Municipio Nechi, Santa María trail, trail between shrine to oil well, margin of Santa María creek, $8^{\circ} 41^{\prime} 60^{\prime \prime} \mathrm{N}, 74^{\circ} 45^{\prime} 13^{\prime \prime} \mathrm{W}, 60$

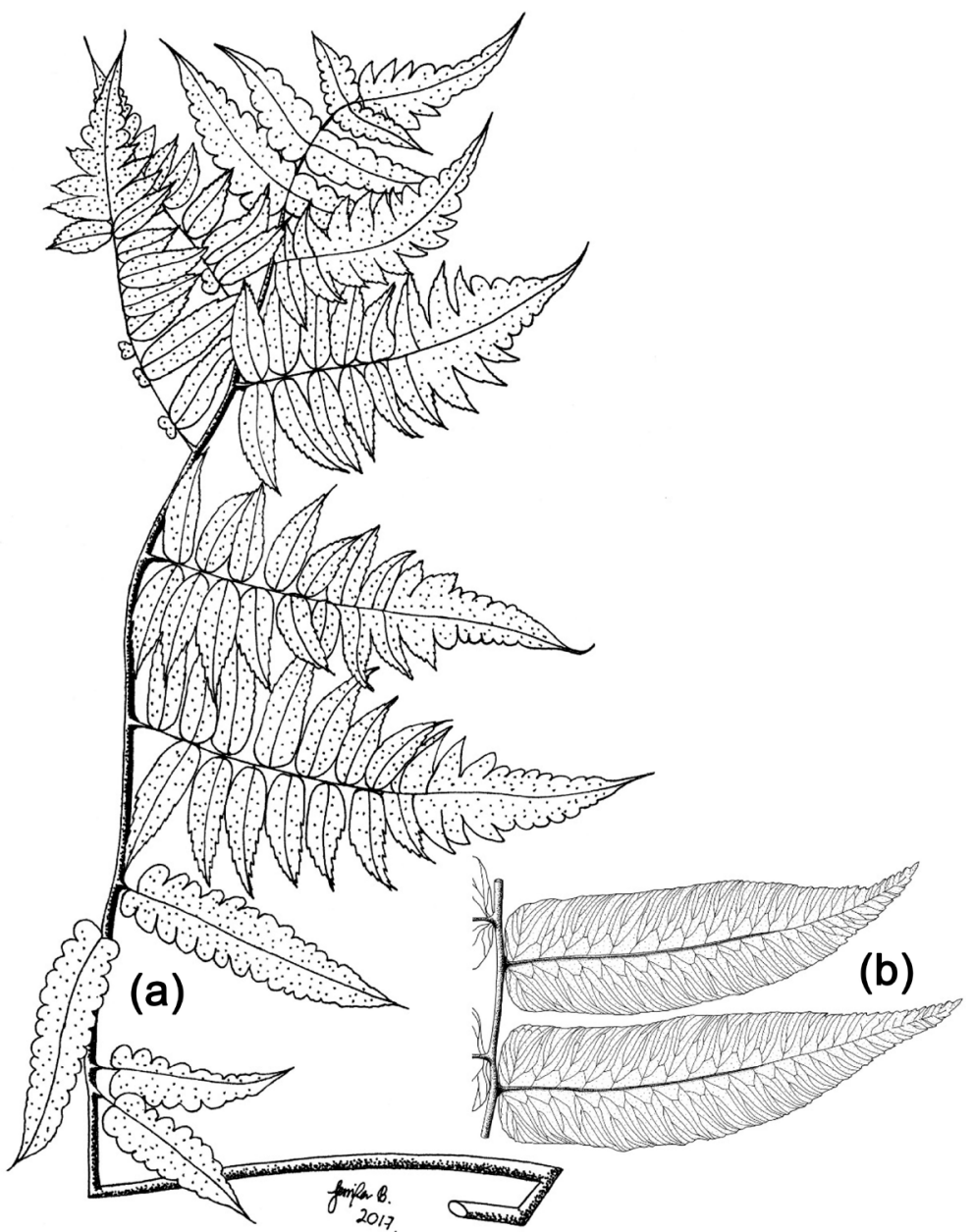

Figure 5. Type specimen of Diplazium rodriguezii A. Rojas ( W. Rodríguez \& W. Uribe 6553, COL). (a) General aspect of specimen; (b) Abaxial blade detail. 
m, 1 Mar 2010, W. Rodríguez \& W. Uribe 6553 (holotype: COL; isotype: MEDEL).

Diagnoses. Diplazium rodriguezii A. Rojas differs from D. tungurahuae (Sodiro) C. Chr. because have abaxially glabrous rachis and costae; 4 - 5 times longer than wide and entire pinnules; costules adaxially without wings; abaxially glabrous veins and reticulate along costae and between pinnate veins.

Description. Rhizome not seen; fronds ca. $170 \mathrm{~cm}$ long; stipe $32.5-49.5 \times 0.6$ - $0.9 \mathrm{~cm}$, yellowish-brown throughout including rachis and costae, scaly only at base, the scales $6-8 \times$ ca. $1 \mathrm{~mm}$, linear-deltate, brown, marginally entire; blade ca. $120 \times 80 \mathrm{~cm}$, elliptic to ovate, 2-pinnate at center, 1-pinnate at base and apex, reduced at two ends, presumable pinnatifid and acuminate at apex, papyraceous, glabrous in both surfaces, discolorous, lighter abaxially; rachis yellowish-brown to brown, glabrous or scaly only in the onion with costae, the scales $2-3 \times$ less than $0.5 \mathrm{~mm}$, marginally with bifid teeth; pinnae 10 - 12 pairs, $15-40 \times(3.5-) 4$ $22 \mathrm{~cm}$, lanceolate to lanceolate-oblong, alternate, lobulate to pinnate, lanceolate-oblong, basally truncate, the basal pinnae inequilateral at base with pedicle longer at basiscopic side, pediculate to $2 \mathrm{~cm}$, apically long acuminate; lobes of basal and apical pinnules lobulate to pinnatifid, the lobes entire at base and center, apically obtuse to rounded and with dentate margin; free pinnules $9-11.5 \times$ 2.0 - $2.6 \mathrm{~cm}, 3$ - 5 pairs, lanceolate-oblong, basally truncate, medially with entire margin, apically falcate, long acuminate with serrate margin; veins reticulate along costae and between pinnate veins, free and single after that, brown, glabrous; sori not seen.

Etimology. The new species is dedicated to Wilson Rodríguez, Colombian pteridologist and collector of type material.

Distribution. Known only from the type collection of Municipio Nechi, Antioquia, Colombia at $60 \mathrm{~m}$.

Notes. Diplazium rodriguezii A. Rojas differs from D. tungurahuae (Sodiro) C. Chr. because have abaxially glabrous (vs. pubescent and sparsely scaly throughout) rachis and costae; 4 - 5 times longer than wide (vs. 3 - 3.5 times) and entire (vs. most of them deeply lobed to pinnatifid (sometimes subentire)) pinnules; adaxially without wings (vs. provided with low wings of tissue perpendicular to the plane of the lamina) costules; abaxially glabrous (vs. scaly) veins and reticulate along costae and between pinnate veins (vs. all free). Also is similar to D. venulosum (Baker) Diels in 2-pinnate fronds and reduced at both ends blades, but differ in its stipe, abaxially glabrous (vs. densely scaly throughout) rachis and costae; pinnae with 3 - 5 pairs of free pinnules (vs. 12 - 16 pairs of free pinnules) and they entire basal and medially (vs. commonly serrate to crenateserrate).

\section{Conclusion}

The species here described have very restricted geographical distributions, probably because more explorations are necessary in the Neotropics for discover species adapted to very specialized micro-habitats and because the Diplazium 
genus is few studied.

\section{Acknowledgements}

This work was made possible thanks to Vicerrectoría de Investigación of Universidad Nacional de Costa Rica (UNA) for financing this project through Observatorio Ambiental project and Sistema Nacional de Áreas de Conservación (SINAC) for the authorization to make collections in the Costa Rican Protected Areas. Thanks also to Herbario Nacional de Costa Rica, Museo Nacional de Costa Rica (CR) and Herbario Nacional Colombiano, Instituto de Ciencias Naturales, Universidad Nacional de Colombia (COL), and their curators for good attention and facilitates. Thanks to Karen Bermúdez Barrantes, Jasmín Mejía Vargas, and Pablo Muñoz Cambronero for the excellent drawings. To the anonymous reviewers for their help; and to all who, in one way or another, made this work possible.

\section{References}

[1] Tryon, R.M. and Stolze, R.G. (1991) Pteridophyta of Peru. Part IV. 17. Dryopteridaceae. Field Museum of Natural History, Chicago, New Series 27, 65-88.

[2] Mickel, J.T. and Smith, A.R. (2004) The Pteridophytes of Mexico. Memoirs of the New York Botanical Garden, 88, 251-268 + 813-818.

[3] Moran, R.C. (2011) Neotropical Genera of Ferns and Lycophytes. Organization for Tropical Studies, San José, 407 p.

[4] Schuettpelz, E. and Pryer, K.M. (2007) Fern Phylogeny Inferred from 400 Leptosporangiate Species and Three Plastid Genes. Taxon, 56, 1037-1050. https://doi.org/10.2307/25065903

[5] Adams, C.D. (1995) Diplazium. In: Moran, R.C. and Riba, R., Eds., Flora Mesoamericana. Vol.1. Psilotaceae a Salviniaceae, Universidad Nacional Autónoma de México, Mexico city, 228-246. http://www.mobot.org/mobot/tropicos/meso/homep_sp.htm

[6] Gómez, L.D. and Arbeláez, A.L. (2009) Helechos. In: Stevens, W.D., Montiel, O.M. and Pool, A., Eds., Flora de Nicaragua, Helechos. Vol. 4. Monographs in Systematic Botany from the Missouri Botanical Garden, Missouri Botanical Garden Press, St. Louis, $56-62+116+235-238$.

[7] Murillo, M.T., Murillo, J., León, A. and Triana, L.A. (2008) Los Pteridófitos de Colombia. Arfo, Bogotá, 533 p.

[8] Smith, A.R. (1995) Pteridophytes. In: Berry, P.E., Holst, B.K. and Yatskievych, K., Eds., Flora of the Venezuelan Guayana. Volume 2. Pteridophytes, Spermatophytes. Acanthaceae-Araceae, Timber Press, Portland, 1-327.

[9] Stolze, R.G. (1981) Ferns and Fern Allies of Guatemala. Part II. Polypodiaceae. Field Museum of Natural History, Chicago, New Series 6, 1-522.

[10] Stolze, R.G., Pacheco, L. and Øllgaard, B. (1994) Polypodiaceae-Dryopteridoideae-Physematieae, In: Harlingy, G. and Andersson, L., Eds., Flora of Ecuador, ${ }^{\circ} 49$, Swedish Natural Science Research Council, Stockholm, 3-104.

[11] Adams, C.D. (1992) Eleven New Species, a New Variety, and a New Varietal Combination in the Fern Genera Asplenium and Diplazium in Central America. Novon, 2, 290-298. http://www.jstor.org/stable/3391480 
https://doi.org/10.2307/3391480

[12] Kessler, M. and Smith, A.R. (2007) New Species and Other Nomenclatural Changes for Ferns from Bolivia. Brittonia, 59, 186-197. https://doi.org/10.1663/0007-196X(2007)59[186:NSAONC]2.0.CO;2

[13] Lorea, F.G. and Smith, A.R. (1999) Two New Fern Species from Southern Mexico. American Fern Journal, 89, 181-186. https://doi.org/10.2307/1547420

[14] Mickel, J.T. and Smith, A.R. (2000) Three New Pteridophytes from Mexico. Brittonia, 52, 234-237. https://doi.org/10.2307/2666572

[15] Pacheco, L. (2004) A New Species of Diplazium (Woodsiaceae) from Ecuador. Brittonia, 56, 121-123. https://doi.org/10.1663/0007-196X(2004)056[0121:ANSODW]2.0.CO;2

[16] Pacheco, L. and Moran, R.C. (1999) Monograph of the Neotropical Species of Callipteris with Anastomosing Veins (Woodsiaceae). Brittonia, 51, 343-388. https://doi.org/10.2307/2666519

[17] Pacheco, L. and Smith, A.R. (2006) Diplazium condorense (Athyriaceae), a New Species from Ecuador. Brittonia, 58, 376-378. https://doi.org/10.1663/0007-196X(2006)58[376:DCAANS]2.0.CO;2

[18] Rojas, A.F. (1996) Aportes a la Flora Pteridophyta Costarricense. II. Taxones nuevos. Brenesia, 45-46, 33-50.

[19] Rojas, A.F. (2008) Five New Species and New Records in Diplazium (Athyriaceae) from the Neotropics. Métodos en Ecología y Sistemática, 3, 30-40.

[20] Rojas, A.F. (2009) Dos especies nuevas y cuatro nuevos registros de Diplazium (Athyriaceae) con fronda pinnada para el neotrópico. Métodos en Ecología y Sistemática, 4, 23-28.

[21] Rojas, A.F. (2012) Novedades en Diplazium (Woodsiaceae) con frondas pinnado-lobuladas para el neotrópico. Actualidades Biológicas, 34, 153-159.

[22] Thiers, B. (2016) Index Herbariorum: A Global Directory of Public Herbaria and Associated Staff. New York Botanical Garden's Virtual Herbarium.

http://sweetgum.nybg.org/science/ih/ 